\title{
Optimization of the Balance between Protein, Lipid and Carbohydrate in Diets for Lumpfish (Cyclopterus lumpus)
}

\author{
Kristin Hamre ${ }^{D},{ }^{1}$ Gerd Marit Berge, ${ }^{2}$ Øystein Sæle, ${ }^{1}$ Elisabeth Holen, ${ }^{1}$ \\ Katerina Kousoulaki, ${ }^{3}$ Sofie Charlotte Remo, ${ }^{1}$ Åshild Krogdahl, ${ }^{4}$ and Ingrid Lein ${ }^{2}$ \\ ${ }^{1}$ Institute of Marine Research (IMR), Bergen, Norway \\ ${ }^{2}$ Nofima AS, Sunndalsøra, Norway \\ ${ }^{3}$ Nofima AS, Bergen, Norway \\ ${ }^{4}$ Norwegian University of Life Sciences (NMBU), Ås, Norway
}

Correspondence should be addressed to Kristin Hamre; kha@hi.no

Received 22 October 2021; Revised 2 January 2022; Accepted 17 January 2022; Published 16 February 2022

Academic Editor: Zhen-Yu Du

Copyright (C) 2022 Kristin Hamre et al. This is an open access article distributed under the Creative Commons Attribution License, which permits unrestricted use, distribution, and reproduction in any medium, provided the original work is properly cited.

The aim of this study was to investigate how the dietary balance between protein, lipid, and carbohydrate affects growth, welfare, and health with focus on immune responses, in lumpfish of body weight ranges 1.7-10 g and 15-50 g. A three-component mixture design, with simultaneous variation of the three macronutrients was applied. Growth, tissue and plasma nutrient composition, welfare, cataract frequency, and immune responses in leukocytes isolated from the fish head kidney were studied. Most responses were linear and driven by dietary lipid level, with minor effects of carbohydrate and protein. The growth in 1.7-10 g fish followed a special cubic model with no clear optimum. The fastest growth in the 15-50 g fish was obtained with the diet containing 55\% protein, $17 \%$ fat, and $6 \%$ carbohydrate. The high dietary levels of lipid also gave high lipid levels in the tissues and a trend of improved welfare score, but there were no effects on cataract. The diets with minimum and maximum protein gave suboptimal immune responses in isolated head kidney cells of the $15-50 \mathrm{~g}$ fish, while the fastest growing fish showed normal immune responses. We propose that diets for lumpfish from 10-50 g body weight should contain approximately 55\% protein, minimum 10\% lipid, and maximum 10\% carbohydrate. These diets will also be suitable for lumpfish of 1.7-10 g.

\section{Introduction}

The ectoparasite, salmon louse (Lepeophtheirus salmonis) is one of the largest challenges for the salmon farming industry. The use of cleaner fish (CF herein) offers an alternative to chemotherapeutants which are used less today following increasing drug resistance [1-3]. Mechanical and thermal delousing methods are currently the most widely used in Norway and are also being increasingly implemented elsewhere. However, these methods are stressful for the salmon and frequently lead to poor welfare [3]. The use of CF is a less stressful delousing method compared to mechanical and thermal delousing, due to less handling of the salmon, and is therefore a good solution for salmon welfare [4-6]. However, the welfare [7] of the cleaner fish in salmon cages is far from satisfactory [8-10].
Several wild wrasse species are used to control sea lice as well as the two hatchery-produced species, Lumpfish (Cyclopterus lumpus) and ballan wrasse (Labrus bergylta). Lumpfish is by far the species used in the highest number, and in 2019, almost 40 million farmed lumpfish were deployed in salmon cages in Norway alone [11]. Unfortunately, the welfare of these fish is poor and the majority die in the salmon pens [12]. Supplementary food in sea cages is vital to maintain the welfare of CF [9]. Leclercq et al. [13] noted that supplementary feeding of CF deployed within commercial salmon pens is necessary to maintain the $\mathrm{CF}$ nutritional condition, welfare, and delousing efficacy. Powel et al. [6] also suggest that around a third of the lumpfish die of starvation after only a few months and a large part of the fish that eat die of various infectious diseases. A balanced 
diet covering the nutritional requirements is pivotal for good welfare and a functional immune system.

Imsland et al. [14] concluded that lumpfish show a strong opportunistic feeding behaviour. In the net pen, lumpfish seem to target multiple food sources such as crustacean and hydrozoan species in the water column or on the nets, as well as salmon pellets. Studies suggest that nutritional problems may occur if lumpfish only feed on salmon pellets after deployment [14]. Sayer et al. [15] fed wild-caught lumpfish juvenile diets containing high or low fat. The survival was highest in fish fed a low-fat diet although the high-fat diet provided more rapid growth. Research on feeding strategies [5] and tolerance for plant ingredients in lumpfish feeds [16] has been published. However, the nutritional requirements of lumpfish remain largely unknown. The macronutrient requirements of other fish species are highly species dependent and change during the life cycle $[17,18]$. Therefore, the optimal dietary macronutrient composition should be determined for each species and developmental stage.

Another question to be asked is how to define the optimum dietary macronutrient composition. In fish produced for human consumption, growth is in this respect an important parameter. However, farmers do not wish that lumpfish grow too fast, as full immunity may take up to 630 to $1000 \mathrm{~d}^{\circ}$ after vaccination [19]. Immunity is desired before the fish are stocked in the pens, at which timepoint they should not be too big because the larger lumpfish are less effective as CF. Health and welfare parameters are also important to evaluate to find the optimal dietary composition.

As mentioned above, lumpfish are susceptible to a wide range of pathogens that may cause diseases and mortalities [20], and extensive efforts are made to develop efficient vaccines. However, experience until now may indicate that vaccination is a less effective tool for lumpfish than for salmon [21]. Nutrition has a great impact on the immune responses, and in humans, malnutrition is considered the largest cause of immunodeficiency worldwide [22]. Studies using a head kidney leukocyte model showed that diet composition may influence immune responses against bacteria and virus in fish [23, 24]. In the present study, a similar model was implemented, testing the immune response in lumpfish fed the three most extreme experimental diets. Another large challenge in lumpfish farming is the high prevalence of cataract which can affect up to $100 \%$ of the fish \{Jonassen, 2017 \#4671\}.

Lumpfish can be fed formulated diets from the first feeding, even though their stomach is not fully developed at this stage. An ontogeny study of the lumpfish stomach histology showed a gradual formation of gastric glands from 10 to 50 days posthatch [25]. As for other species, the stomach may not be fully functional even when gastric glands are present [26]. In red porgy (Pagrus pagrus), pepsinogen expression and stomach $\mathrm{pH}$ developed several days after the differentiation of gastric glands [27]. A functional stomach is a prerequisite for optimal utilization for digestion and utilization of "warm" extruded pellet in most marine fish larvae [28]. Therefore, this study started with an experiment to estimate the optimal developmental stage for starting the nutritional study.

The main aim of the current study was to clarify how the dietary balance between protein, lipid, and carbohydrate affects growth and health with focus on growth, body composition, welfare, cataracts, and immune responses in lumpfish of two size ranges.

\section{Material and Methods}

This study includes two feeding trials covering two body weight ranges of lumpfish: (a) $1.7 \mathrm{~g}$ to about $10 \mathrm{~g}$ and (b) $15 \mathrm{~g}$ to about $50 \mathrm{~g}$, representing the hatchery period until vaccination and the period from vaccination until deployment in salmon cages. The feeding trials were conducted in accordance with Norwegian laws and regulations concerning experiments with live animals. Experiments were overseen by the Norwegian Food Safety Authority. The experiments in the present study were not regarded as harmful to the experimental animals and therefore did not need approval.

\subsection{Experimental Design, Diet Composition, and Processing.} The experiments were conducted implementing a threecomponent mixture design [29], set up using Design Expert ver. 8.0.4. (Stat-Ease Inc. MN, USA). This design allows variation of protein, lipid, and carbohydrate simultaneously, continuously, and systematically, within given limits. Using 12 different diets (i.e., treatments), of which 11 diets were administered to fish in single tanks, it was possible to cover a wide range of nutrient compositions (Figure 1). One diet was fed to fish in 3 tanks to obtain a measure of tank variation. The experimental diets were produced at the Feed Technology Centre of Nofima in Bergen, Norway, in the same production series, using a Wenger TX-52 co-rotating twin-screw extruder with $150 \mathrm{kgh}^{-1}$ capacity. The dietary oil was added in the different feed mixes prior to extrusion. The settings of the extruder were "normal"; i.e., the production can be upscaled to a feed factory (extruder settings considered: screw configuration $(D)$, die opening $(1.5 \mathrm{~mm})$, knife speed (2671-3108 rpm), SME (6.5-9.5 kW), feed rate $\left(110-150 \mathrm{~kg} \mathrm{~h}^{-1}\right)$, and amount of steam $\left(10-12 \mathrm{kgh}^{-1}\right)$ and water $\left(0.16-0.18 \mathrm{~kg} \mathrm{~min}^{-1}\right)$ added to the process). The ingoing temperature of the feed mass in the extruder was $79-84^{\circ} \mathrm{C}$ and the outgoing $103-118^{\circ} \mathrm{C}$. The produced pellets were air-dried in a carousel dryer (Model 200.2, Paul Klöckner $\mathrm{GmbH}$, Nisteral, Germany) at $85^{\circ} \mathrm{C}$ for $10-12 \mathrm{~min}$ to a final moisture level between 6.36 and $8.26 \%$. The size of the dried pellets was approx.1.5 $-1.7 \times$ approx. $2.3 \mathrm{~mm}$ with bulk density between 443 and $582 \mathrm{~g} / \mathrm{L}$. Adequate amounts of each diet were milled and sieved to different crumble sizes $(0.15-2.3 \mathrm{~mm})$ to fit the mouth opening of fish at the different growth stages in the two feeding trials. More in detail, the pellet size fractions produced were of the following size ranges: $0.15-0.30 \mathrm{~mm}, 0.30-0.45 \mathrm{~mm}, 0.45-0.60 \mathrm{~mm}, 0.60$ $0.80 \mathrm{~mm}, 0.80-1.00 \mathrm{~mm}, 1.00-1.25 \mathrm{~mm}, 1.25-1.60 \mathrm{~mm}$, and $1.6-2.3 \mathrm{~mm}$. The variation in protein, lipid, and carbohydrate content of the diets was $43-68 \%, 4-17 \%$, and 6-17\%, respectively. Diet formulation and analyzed composition of macronutrients are presented in Table 1.

2.2. Fish Experiments. A preliminary study was done before start of Experiment 1 to estimate the time of maturation of the gastric glands. First-feeding larva were fed a commercial 


\begin{tabular}{lcccc}
\hline Diet & Prot & Lipid & CH & SUM \\
\hline 1 & 68 & 4 & 6 & 78 \\
2 & 60 & 12 & 6 & 78 \\
3 & 55 & 17 & 6 & 78 \\
4 & 66 & 4 & 8 & 78 \\
5 & 58 & 12 & 8 & 78 \\
6 & 53 & 17 & 8 & 78 \\
7 & 60 & 4 & 14 & 78 \\
8 & 52 & 12 & 14 & 78 \\
9 & 47 & 17 & 14 & 78 \\
10 & 56 & 4 & 18 & 78 \\
11 & 48 & 12 & 18 & 78 \\
12 & 43 & 17 & 18 & 78
\end{tabular}

(a)

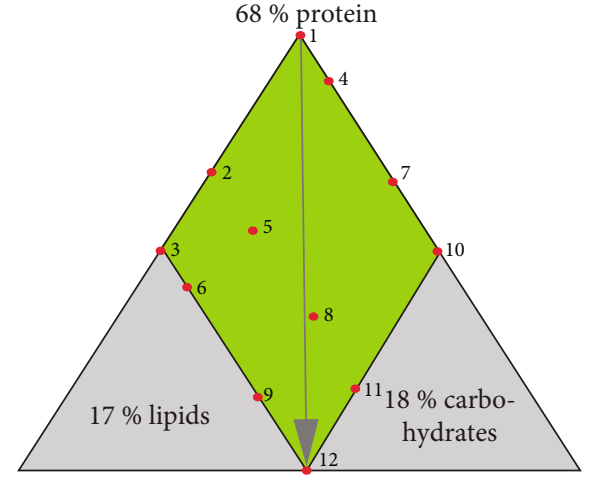

(b)

Figure 1: Experimental design. (a) Table showing the composition of macronutrients in the diets (\% of wet weight; Prot: Protein; CH: carbohydrate). (b) Figure showing the distribution of diet compositions within chosen borders. The green fraction inside the triangle represents the area of variation of protein (68-43\%), lipid (6-17\%), and carbohydrate (4-18\%). The grey arrow represents the gradient of protein supplementation. The red dots represent the numbered diets. Diet 5 was fed to fish in three tanks, and the other 11 diets were fed to fish in one tank each.

agglomerated diet (Otohime C1@). At different sizes (0.3-16.6 g), fish were sampled and killed by an overdose of the anesthetic Finquel@. The sampling was done less than 15 minutes after the last meal. The abdominal organs were extracted before the stomach was separated and opened. $\mathrm{pH}$ was then measured using a $\operatorname{Rota}^{\circledR} \mathrm{pH}$ paper covering the area pH 5.0-8.0 (Figures 2(a)-2(c)).

The gastric $\mathrm{pH}$ stayed high until the fish reached $1-2 \mathrm{~g}$ body weight (Figure $2(\mathrm{~d})$ ). At this stage, the $\mathrm{pH}$ dropped from 8 to 5 indicating that regulation of the acid secretion was not fully established before the fish reached a minimum weight of $1 \mathrm{~g}$. These results were used to decide when the custom-made extruded experimental diets could be introduced in Experiment 1.

2.2.1. Experiment 1 (1.7-10 Grams). Eggs from wild caught lumpfish were hatched at a commercial hatchery at the west coast of Norway. The larvae were first fed using Otohime $\mathrm{C} 1 \mathrm{C}^{\circ}$ and raised until $1.1 \mathrm{~g}$ mean weight before transport to the Nofima research facilities at Sunndalsøra, Norway. At arrival, the fish were distributed to 15 tanks by biomass and number. The tanks were $150 \mathrm{~L}$ and cylindrical, with grey walls and conical bottoms. The fish were given 24 hours light from single lamps over each tank. The tanks were supplied with UV-treated $10 \mu \mathrm{m}$ filtered seawater with a mean temperature of $11.5^{\circ} \mathrm{C}\left(\min 10.1^{\circ} \mathrm{C}, \max 12.0^{\circ} \mathrm{C}\right)$. The water flow was set to $41 / \mathrm{min}$ and oxygen adjusted to $80-100 \%$ by adding oxygen to the water holding tank when needed. Feed was distributed continuously (every $10 \mathrm{~min}$ ) using small automatic belt feeders mounted on each tank. The feeders released feed for 45 seconds followed by a 15-minute pause. Temperature was recorded daily, and oxygen was measured and adjusted 2-3 times per week. Dead fish were removed daily, counted, and weighed. The trial lasted for 30 days.

The biomass was $570 \mathrm{~g}$ per tank, and the average number of fish was 508 in each tank when the fish were distributed to the tanks. Fish in all tanks were fed a commercial diet (Gemma micro(C) during the first seven days before start of the experiment. Thereafter, the experimental diets were fed to fish in 14 tanks while fish in one extra tank were fed the commercial diet and used as a reference for fish body growth. The fish were fed to satiation, and the feed rations increased from 10 to $55 \mathrm{~g} /$ tank during the experimental period. The fish were fed $0.8 \mathrm{~mm}$ pellets until $2 \mathrm{~g}$ size, $1.0 \mathrm{~mm}$ until $4 \mathrm{~g}$, and $1.2 \mathrm{~mm}$ until $10 \mathrm{~g}$. Due to the small pellet sizes, feed intake could not be recorded by our system. The average fish body weight was $1.75 \mathrm{~g}$ at the start of Experiment 1, i.e., seven days after distribution of fish. After one week, the biomass was reduced by 100 individuals weighed by bulk per tank. After another two weeks, 50 individuals per tank were removed and bulk weighed. The bulk weights were used to calculate mean body weights and growth rates and for adjustments of feed ratios and pellet sizes.

2.2.2. Experiment 2 (15-50 Grams). Lumpfish were hatched and raised until vaccination (Amarine micro 4-2, Pharmaq()) at approximately $10 \mathrm{~g}$ body weight at a commercial hatchery at the west coast of Norway. One week after vaccination, the fish were transported by truck for two hours to the Nofima research facilities at Sunndalsøra, Norway. As the fish were left to recover for one week after vaccination before transport to Nofima, they reached at mean body weight of 14.8 grams before the start of Experiment 2 . Ninety individual juveniles were counted for each tank, and bulk weighed before distribution to 14 experimental tanks as those used in Experiment 1. One extra tank was used as reference, in which fish were fed a commercial diet (Atlantic Gold $\odot$, Skretting). Temperature and oxygen were set at the same levels as in Experiment 1. Temperature was recorded daily, and oxygen was adjusted 2-3 times per week. Dead fish were removed daily, counted, and weighed. The fish were fed to satiation, and the feed rations increased from 30 to $68 \mathrm{~g} / \operatorname{tank}$ in tanks with the highest appetite. The fish were fed $1-1.6 \mathrm{~mm}$ pellets until $20 \mathrm{~g}$ size and $1.6-2.3 \mathrm{~mm}$ until the end of the experimental period. Due to the small pellet sizes, feed intake could not be recorded by our system. The experiment lasted for 6 weeks. 
TABLE 1: Trial diet formulation and proximate composition.

\begin{tabular}{|c|c|c|c|c|c|c|c|c|c|c|c|c|}
\hline Diet no & 1 & 2 & 3 & 4 & 5 & 6 & 7 & 8 & 9 & 10 & 11 & 12 \\
\hline \multicolumn{13}{|l|}{ Basic mix: } \\
\hline Fish meal ${ }^{1}$ & 24.50 & 24.50 & 24.50 & 24.50 & 24.50 & 24.50 & 24.50 & 24.50 & 24.50 & 24.50 & 24.50 & 24.50 \\
\hline Krill hydrolysate ${ }^{3}$ & 3.00 & 3.00 & 3.00 & 3.00 & 3.00 & 3.00 & 3.00 & 3.00 & 3.00 & 3.00 & 3.00 & 3.00 \\
\hline Vitamin mix & 2.2435 & 2.2435 & 2.2435 & 2.2435 & 2.2435 & 2.2435 & 2.2435 & 2.2435 & 2.2435 & 2.2435 & 2.2435 & 2.2435 \\
\hline Krill oil $^{4}$ & 1.00 & 1.00 & 1.00 & 1.00 & 1.00 & 1.00 & 1.00 & 1.00 & 1.00 & 1.00 & 1.00 & 1.00 \\
\hline Mineral $\operatorname{mix}^{5}$ & 0.84 & 0.84 & 0.84 & 0.84 & 0.84 & 0.84 & 0.84 & 0.84 & 0.84 & 0.84 & 0.84 & 0.84 \\
\hline Lys & 0.5 & 0.5 & 0.5 & 0.5 & 0.5 & 0.5 & 0.5 & 0.5 & 0.5 & 0.5 & 0.5 & 0.5 \\
\hline Choline chloride & 0.5 & 0.5 & 0.5 & 0.5 & 0.5 & 0.5 & 0.5 & 0.5 & 0.5 & 0.5 & 0.5 & 0.5 \\
\hline Cholesterol & 0.5 & 0.5 & 0.5 & 0.5 & 0.5 & 0.5 & 0.5 & 0.5 & 0.5 & 0.5 & 0.5 & 0.5 \\
\hline Aquate $^{5}$ & 0.35 & 0.35 & 0.35 & 0.35 & 0.35 & 0.35 & 0.35 & 0.35 & 0.35 & 0.35 & 0.35 & 0.35 \\
\hline Taurine & 0.2 & 0.2 & 0.2 & 0.2 & 0.2 & 0.2 & 0.2 & 0.2 & 0.2 & 0.2 & 0.2 & 0.2 \\
\hline Biomoss & 0.05 & 0.05 & 0.05 & 0.05 & 0.05 & 0.05 & 0.05 & 0.05 & 0.05 & 0.05 & 0.05 & 0.05 \\
\hline Carop. Pink & 0.05 & 0.05 & 0.05 & 0.05 & 0.05 & 0.05 & 0.05 & 0.05 & 0.05 & 0.05 & 0.05 & 0.05 \\
\hline Yttrium oxide & 0.01 & 0.01 & 0.01 & 0.01 & 0.01 & 0.01 & 0.01 & 0.01 & 0.01 & 0.01 & 0.01 & 0.01 \\
\hline \multicolumn{13}{|l|}{ Varying ingredients: } \\
\hline Cod muscle meal $^{2}$ & 30.5 & 26.1 & 23.3 & 28.4 & 24.0 & 21.2 & 23.4 & 19.1 & 16.3 & 20.0 & 15.6 & 12.9 \\
\hline Fish oil $^{1}$ & 0.05 & 7.90 & 12.85 & 0.10 & 7.95 & 12.90 & 0.35 & 8.15 & 13.00 & 0.50 & 8.25 & 13.10 \\
\hline Wheat gluten & 30.50 & 26.10 & 23.33 & 28.38 & 23.98 & 21.20 & 23.43 & 19.08 & 16.30 & 19.95 & 15.58 & 12.85 \\
\hline Wheat meal & 1.00 & 1.50 & 1.80 & 5.10 & 5.60 & 5.90 & 14.50 & 15.05 & 15.40 & 21.15 & 21.70 & 22.05 \\
\hline $\mathrm{NaH}_{2} \mathrm{PO}_{4}$ & 4.20 & 4.65 & 4.95 & 4.30 & 4.75 & 5.05 & 4.55 & 4.90 & 5.25 & 4.70 & 5.15 & 5.40 \\
\hline \multicolumn{13}{|c|}{ Preplanned formulation, g/100 g DM } \\
\hline Protein & 74.9 & 70.0 & 60.1 & 71.9 & 67.0 & 57.1 & 64.9 & 59.9 & 50.0 & 60.0 & 55.0 & 44.9 \\
\hline Lipid & 5.1 & 10.0 & 20.0 & 5.1 & 10.0 & 20.0 & 5.2 & 10.1 & 20.0 & 5.0 & 10.0 & 20.1 \\
\hline Carbohydrate & 5.0 & 5.0 & 5.0 & 7.9 & 8.0 & 8.0 & 14.9 & 15.0 & 15.0 & 20.0 & 20.0 & 20.0 \\
\hline Ash & 15.0 & 15.0 & 15.0 & 15.0 & 15.0 & 14.9 & 15.0 & 15.0 & 15.0 & 15.0 & 15.0 & 15.0 \\
\hline \multicolumn{13}{|c|}{ Analyzed composition, $\mathrm{g} / 100 \mathrm{~g}$ as is } \\
\hline Crude protein & 68.0 & 62.0 & 58.0 & 65.0 & 58.0 & 55.0 & 59.0 & 52.0 & 48.0 & 54.0 & 48.0 & 45.0 \\
\hline Total lipid & 4.0 & 11.8 & 16.4 & 4.1 & 11.9 & 16.9 & 4.2 & 12.0 & 16.5 & 4.5 & 12.3 & 17.3 \\
\hline Carbohydrates & 5.9 & 6.0 & 5.8 & 8.3 & 8.2 & 8.1 & 13.7 & 13.6 & 13.7 & 16.9 & 17.5 & 17.7 \\
\hline Ash & 11.6 & 11.2 & 11.2 & 11.2 & 11.4 & 11.4 & 11.3 & 11.1 & 11.2 & 11.2 & 11.1 & 10.9 \\
\hline Dry matter & 92.0 & 93.0 & 93.0 & 92.0 & 92.0 & 92.0 & 92.0 & 92.0 & 92.0 & 91.0 & 92.0 & 93.0 \\
\hline
\end{tabular}

${ }^{1}$ Norsildmel, Egersund, Norway; ${ }^{2}$ Seagarden, Karmøy, Norway; ${ }^{3}$ Olympic, Herøy, Norway; ${ }^{4}$ Aker BioMarine, Oslo, Norway; ${ }^{5}$ Alltech Inc., Dunboyne, Ireland.

2.3. Sampling. All samplings were performed between 9.00 and 16.00. The fish were sedated with metomidate $(5 \mathrm{mg} / \mathrm{L})$ before blood sampling to reduce stress and increase in cortisol levels. After blood sampling, the fish were killed by an overdose of Flumequin $($ (200-220 mg/L) before further sampling.

At termination of the experiments, 20 fish per tank in Experiment 1 and 6 fish per tank in Experiment 2 were sampled for the liver and muscle tissues. In Experiment 2, connective tissue was also sampled. Body weight and length, and weight of the liver and gonads (when present) were recorded. The liver and muscle tissues and subcutaneous connective tissue in trial 2 were pooled from 10 fish in Experiment 1 and from 6 fish in Experiment 2, homogenized, frozen, and transported to IMR on dry ice for macronutrient analyses. Blood samples were collected from the same fish (Vacuette tubes, $3 \mathrm{~mL}$, with serum clot activator). Serum was frozen at $-20^{\circ} \mathrm{C}$ prior to analysis of lactate, glucose, magnesium, cholesterol, and triacylglycerols (TAG).
Six fish per tank from the most extreme diets (diet 1 ( $\max$ protein), diet 3 (max lipid, min carbohydrate), and diet 12 (max carbohydrate, max lipid)) were sampled for isolation of head kidney cells which were then exposed to viral and bacterial mimics. 18 fish represented the maximum capacity of processing fish by this method.

Individual weights, lengths, and liver weights were recorded for another 20 fish. From the remaining fish, a sample of 25 individuals was used for assessment of external welfare indicators including cataract scores. The remaining fish in each tank were bulk weighed and counted for the calculation of average body weight. All fish in each tank are included in average weight used for the calculation of growth models.

\subsection{Analyses}

2.4.1. Chemical Analyses. Analyses of proximate composition of feed and fish tissues were performed by routine 
(a)

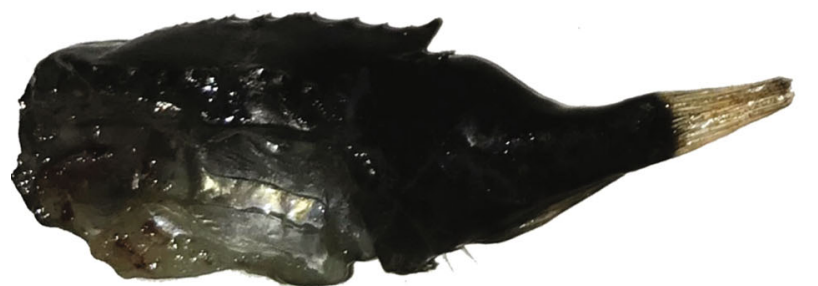

(b)

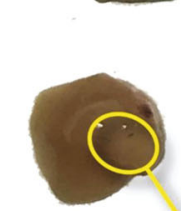

(c)

(d)

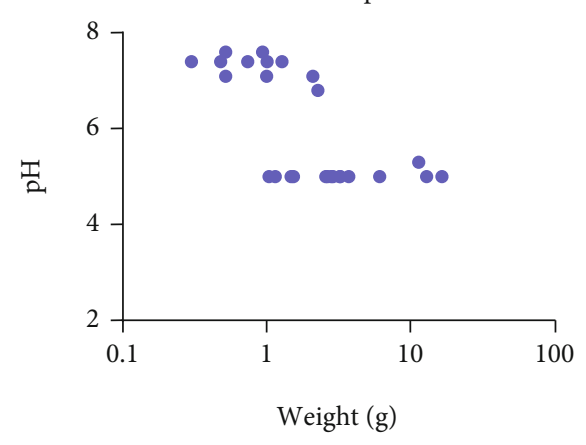

Figure 2: Method for measurement of gastric pH; (a) Lumpfish. (b) Gastrointestinal tract from fish of different sizes. (c) Colorimetric measurement with $\mathrm{pH}$ paper. (d) Gastric $\mathrm{pH}$ in lumpfish larvae from the first feeding until $>10 \mathrm{~g}$.

methods at IMR, Bergen, Norway. Moisture was measured by drying at $103^{\circ} \mathrm{C}$ for $24 \mathrm{~h}$ and ash weighed after burning at $540^{\circ} \mathrm{C}$ and lipid after extraction with ethyl acetate in fish tissue and acid-extraction in fish feed [30] (EU directive 84/4 1983). Nitrogen was measured with a nitrogen analyzer (vario Macro Cube, CN; Elementar Analysensysteme $\mathrm{GmbH}$, Hanau, Germany) according to AOAC official methods of analysis [31] and protein calculated as Nx6.25.

Photometric analyses of cortisol, lactate, glucose, magnesium, cholesterol, and triacylglycerols in serum were done by Nofima, Sunndalsøra, Norway (Pentra C400 HORIBA; HORIBA medical, Montpellier, France).
2.4.2. Cataract and Global Welfare Score. The eyes of the fish were inspected for cataract using a slit lamp (Heine HSK150, Heine Veterinary, Germany). The score for each eye (ranging from 0 to 4 , depending on the percentage coverage of the lens by cataract) was given, and the total score for each fish $(0-8)$ was calculated, based on the procedure given by [32].

External welfare scoring was done according to Noble et al. [33] for 25 individuals from each tank. The scoring included evaluation of the jaws, skin, operculum, and all fins (Table 2). Higher scores indicated more severe conditions, according to the evaluated traits. Each examined fish got one score for each of the mentioned traits. The scores were summed for each fish to a welfare scoring index sum and averaged per tank. The scoring index sum allowed comparison of the effect of different treatments within this experiment. However, this sum index does not allow direct comparisons to OWI evaluations from other experiments using other OWI scoring systems. The average scoring index sum calculated for each tank was used for statistical analysis.

2.4.3. Immune Responses in Head Kidney Cells: Experiment 2. Analyses of simulated immune response in head kidney cells was performed for 6 fish from 3 of the extreme treatments, e.g., diet 1 (high protein (HP)), diet 3 (high lipid, medium protein, low carbohydrate (HL)), and diet 12 (high carbohydrate, low protein, high lipid (HC); Figure 1). Fish from three treatments, only, were used, because this was the maximum capacity of the analyses. For each fish, head kidneys were isolated according to Martins et al. [7]. In short, head kidneys were added to a sterile isolation buffer and the cells were aspirated and squeezed through a $100 \mu \mathrm{M}$ Falcon cell strainer. Washed cell pellets were resuspended in isolation buffer and layered in top of Percoll in a density of $1.08 \mathrm{~g} / \mathrm{mL}$ and centrifuged at $800 \mathrm{~g}(5 \mathrm{~min})$. The cell layer in the interface was collected, and the cells were washed $(2 \mathrm{x})$ and pelleted before resuspending them in complete L-15 medium. Suspensions of $1 \times 10^{7}$ leukocytes were added to 6 well culture plates and kept over-night at $9^{\circ} \mathrm{C}$ in a normal atmosphere incubator, before exposing the leukocytes for the bacterial and virus mimics lipopolysaccharide (LPS, $100 \mu \mathrm{g} / \mathrm{mL}$ ) and polyinosinic acid:polycytidylic acid (PIC, $50 \mu \mathrm{g} / \mathrm{mL}$ ), respectively, for an additional $24 \mathrm{~h}$ in the incubator. Untreated cultures were included as controls. For harvesting, pellets of washed leukocytes were added $600 \mu \mathrm{L}$ RTL-plus buffer (RNeasy Plus kit, Qiagen) and frozen at $-80^{\circ} \mathrm{C}$ before RNA extraction.

Total RNA was extracted using RNeasy plus kit (Qiagen) according to the instruction of the manufacturer. The quantity and quality of RNA were assessed using the NanoDrop ND-1000UV spectrophotometer and Agilent 2100 Bioanalyzer. RNA integrity was assessed using RNA 6000 Nano LabChip kit. RIN values between 9 and 10 indicated that RNA samples were suitable for RT-qPCR. Quantitative real-time RT-RT-qPCR was performed as in Martin et al. [7], using the primers listed in Table S3. Normalization of the target genes was performed using RPS20 as normalization gene. 
TABLE 2: OWI scoring system for lumpfish used in the present experiment.

\begin{tabular}{lcc}
\hline & Examination & Scoring \\
\hline Jaw & Deformity or damage & $0-2$ \\
Skin & Damage or wound & $0-2$ \\
Operculum & Shortened or damaged & $0-2$ \\
Dorsal fin & Deformity, erosion, splitting, & $0-4$ \\
Caudal fin & or wound \\
Pectoral fin & Deformity, erosion, splitting, & $0-4$ \\
Pelvic fin & Deformity, erosion, splitting, & $0-4$ \\
Scoring index sum & or wound & \\
\hline
\end{tabular}

2.5. Calculations and Statistics. Weight gain (WG), growth rate (SGR and TGC), condition factor (CF), and hepatosomatic index (HSI) were calculated according to the following equations:

$$
\begin{aligned}
\mathrm{WG} & =W_{2}-W_{1}, \\
\text { Specific growth rate }\left(\% \mathrm{BW} \mathrm{d} \mathrm{d}^{-1}\right): \mathrm{SGR} & =\left(\ln W_{2}-\ln W_{1}\right)\left(t_{2}-t_{1}\right) * 100, \\
\text { Thermal growth coefficient }: \mathrm{TGC} & =\frac{W_{2}^{1 / 3}-W_{1}^{1 / 3}}{\left(t_{2}-t_{1}\right) \times T} * 1000,
\end{aligned}
$$

where $W_{1}$ and $W_{2}$ are body weights (g) at time (days) $t_{1}$ and $t_{2}$, respectively, and $T$ is average water temperature over the test period.

$$
\begin{array}{r}
\text { Condition factor }(\mathrm{CF})=\frac{\text { body weight }}{(\text { body length })^{3}} \times 100, \\
\text { Hepatosomatic index }(\mathrm{HSI})=\frac{\text { liver weight }}{\text { body weight }} \times 100 \text {. }
\end{array}
$$

Models describing the effects of macronutrient composition on growth, body indices, body composition, welfare score, and cataract were calculated using the software Design Expert ver. 8.0.4. (Stat-Ease Inc., MN, USA) adjusting Scheffè mixed models to the data. These are polynomial models where terms are added as long as the fit improves The terms used in this study were $\mathrm{A}$ *protein concentration (P), B*lipid (L), C*carbohydrate $(\mathrm{CH})$, $\mathrm{AB} * \mathrm{P} * \mathrm{~L}, \mathrm{BC} * \mathrm{~L} * \mathrm{CH}, \mathrm{AC}, \mathrm{P} * \mathrm{CH}$, and $\mathrm{ABC} * \mathrm{P} * \mathrm{~L} * \mathrm{CH}$. Significant models were the linear model with only the main effects being significant and the special cubic model with some of the interaction effects mentioned above being significant. The program chooses the best model based on sequential $p$ value, "Lack of fit" (based on the difference in mean sum of squares between true replicates (midpoint had three replicates) and the deviation between measured and predicted responses for the whole dataset), $R$ squared, and adjusted $R$ squared. Different models were fitted to the data, and the recommended model with the best fit was chosen. When no model had a significant fit to the response data, mean and standard deviation of the total dataset are given. Models and coefficients were considered significant at $p<0.05$.

Gene transcription differences between isolated leukocytes from fish fed the three most extreme diets and exposed to LPS and PIC treatments in vitro were analyzed by twoway ANOVA. Independent variables were treatment (LPS and PIC) and diet, and Tukey's multiple comparison test $(\alpha=0.05)$ was applied. GraphPad Prism version 8.0 software was used. Overall significant dietary differences are indicated by letters $a$ and $b$, while in vitro leukocyte treatment differences, compared to respective controls, are indicated by $*$. Within a diet, treatments in vitro are always compared to respective controls, not challenged with LPS or PIC.

\section{Results}

3.1. Maturation of the Stomach. Maturation of the stomach, indicating the developmental stage at which the fish can acidify the stomach contents is shown in Figure 2. The results showed that $\mathrm{pH}$ decreased from neutral to acidic values when the fish were between 1 and $2 \mathrm{~g}$ showing that the acidification process is immature before this size. Experiment 1 was therefore conducted starting with fish of $1.7 \mathrm{~g}$ body weight.

3.2. Effect of Dietary Macronutrient Balance on Growth, Condition Factor, and Hepatosomatic Index. In fish growing from 1.7 to $10 \mathrm{~g}$ (Experiment 1), the final weight ranged from 10 to $13 \mathrm{~g}$ (Table 3, Figure 3(a)). The relationship with diet composition followed a special cubic model $(p=0.035)$. High weights were associated with two nutrient combinations, one with high lipid, low protein, high carbohydrate, and the other, more pronounced, with low lipid and medium-high protein and carbohydrate. Other growth biomarkers, such as weight gain, SGR, and TGC, followed similar models as final weight (Table 3 and Tables S1 and S2). The length data also followed a special cubic relationship, very similar to the one for weight, with a near significant fit $(p=0.066$, Table 3 and Tables S1 and S2). The condition factor did not respond to the dietary variation (Table 3). Final HSI showed values in the range $1.5-2.4 \%$ of $\mathrm{BW}$ and a linear relationship with diet composition $(p=0.015)$ (Figure S1, Table S1 and S2), high at high lipid, and medium protein, with a negative effect of high carbohydrate.

In fish growing from 15 to $50 \mathrm{~g}$ (Experiment 2), the final fish weight ranged from 48 to $63 \mathrm{~g}$, and responded to variation in diet composition following a linear model $(p=0.002)$ (Table 3, Figure 3(b)) Fish fed the diet with medium protein, maximum lipid, and minimum carbohydrate had maximum growth. Other measures of growth in weight, such as weight gain, SGR, and TGC, followed similar models as final weight (Table S1 and S2). Length and condition factor did not respond to the dietary variation (Table S2).

Final HSI showed values in the range $1.9-2.5 \%$ of BW and a linear relationship with diet composition $(p=0.0003)$ (Table S1 and S2, Figure S1). HSI increased with increasing 
Table 3: Growth and tissue composition. Data series minimum and maximum values, means and standard deviations, coefficient sizes, the model that fitted the data best, and probability that the data distribution is random (no systematic variation). The general regression equation is $\mathrm{Y}=\mathrm{A} *$ protein $+\mathrm{B} * \operatorname{lipid}+\mathrm{C} *$ carbohydrate $+\mathrm{A} * \mathrm{~B} *$ protein $* \operatorname{lipid}+\mathrm{A} * \mathrm{C} *$ protein $*$ carbohydrate $+\mathrm{B} * \mathrm{C} *$ lipid $*$ carbohydrate (nutrients given as \% of w.wt. (Table 1)). Data in bold and bold-italics indicate significance of the coefficients: $p<0.01$; $0.01 \leq p<0.05 ; p \geq 0.05$.

\begin{tabular}{|c|c|c|c|c|c|c|c|c|c|c|}
\hline Response & Min & $\operatorname{Max}$ & Mean & $\mathrm{SD}$ & $A$ & $B$ & $C$ & Interact & Model & $p$ model \\
\hline \multicolumn{11}{|l|}{ Lumpsucker $1.7-10 \mathrm{~g}$} \\
\hline Mortality & 5.1 & 15.4 & 9.9 & 2.8 & & & & & Mean & \\
\hline Final weight (g) & 10.1 & 12.7 & 11.4 & 1.0 & -0.022 & -2.1 & -5.1 & $\mathrm{AC}, \mathrm{BC}^{*}$ & Sp cubic & 0.036 \\
\hline Condition factor & 7.62 & 8.56 & 8.24 & 0.26 & & & & & Mean & \\
\hline \multicolumn{11}{|l|}{ Liver (\%WW) } \\
\hline Protein & 9.9 & 12.1 & 10.6 & 0.6 & 0.14 & 0.069 & 0.18 & & Linear & 0.011 \\
\hline Dry matter & 28 & 41 & 36 & 4.1 & 0.38 & 1.08 & 0.20 & & Linear & $<10^{-4}$ \\
\hline Total fatty acids & 10.3 & 25 & 18.6 & 4.1 & 0.15 & 0.89 & 0.0044 & & Linear & $<10^{-4}$ \\
\hline \multicolumn{11}{|l|}{ Muscle (\%WW) } \\
\hline Protein & 6.1 & 7.5 & 6.73 & 0.432 & 0.088 & 0.13 & 0.039 & & Linear & 0.019 \\
\hline Dry matter & 7.99 & 11 & 9.58 & 0.994 & 0.11 & 0.27 & 0.055 & & Linear & $<10^{-4}$ \\
\hline Total fatty acids & 0.6 & 2.8 & 1.68 & 0.649 & 0.0039 & 0.12 & 0.0094 & & Linear & $<10^{-4}$ \\
\hline Welfare score & 4.25 & 6.4 & 5.4 & 0.6 & & & & & Mean & \\
\hline \multicolumn{11}{|l|}{ Lumpsucker 15-50 g } \\
\hline Mortality (\%) & 0 & 7.78 & 3.25 & 2.67 & & & & & Mean & \\
\hline Final weight (g) & 48.1 & 62.9 & 54 & 4.15 & 0.65 & 1.25 & 0.35 & & Linear & 0.002 \\
\hline Condition factor & 7.0 & 10.2 & 8.1 & 0.9 & & & & & Mean & \\
\hline \multicolumn{11}{|l|}{ Liver (\%WW) } \\
\hline Dry matter & 35 & 46 & 40 & 3 & 0.47 & 0.96 & 0.30 & & Linear & $<10^{-4}$ \\
\hline Total fatty acids & 19 & 35 & 27 & 5 & 0.24 & 1.12 & 0.081 & & Linear & $<10^{-4}$ \\
\hline Protein & 10.1 & 12.7 & 11.1 & 0.85 & 0.16 & 0.0075 & 0.18 & & Linear & $<10^{-4}$ \\
\hline \multicolumn{11}{|l|}{ Muscle (\%WW) } \\
\hline Dry matter & 9.3 & 15.4 & 13 & 2.0 & 0.012 & 0.47 & 0.12 & & Linear & $<10^{-4}$ \\
\hline Total fatty acids & 1.1 & 6.1 & 4.1 & 1.8 & $-7.3 * 10^{-5}$ & 0.35 & 0.027 & & Linear & $<10^{-4}$ \\
\hline Protein & 6.7 & 8.2 & 7.7 & 0.5 & & & & & Mean & \\
\hline Cataract & 3.6 & 5.7 & 4.3 & 0.7 & & & & & Mean & \\
\hline Welfare score ${ }^{2}$ & 4.8 & 6.8 & 6.1 & 0.6 & & & & & Mean & \\
\hline
\end{tabular}

${ }^{*} \mathrm{AB}=0.043, \mathbf{A C}=\mathbf{0 . 1 0} ; \mathbf{B C}=\mathbf{0 . 3 2}, \mathrm{ABC}=-0.004$. Sp cubic: special cubic.

dietary lipid and decreasing protein. There was also a slight positive effect of increasing dietary carbohydrate.

\subsection{Effect of Dietary Macronutrient Balance on Macronutrient} Composition of the Liver, Muscle, and Plasma. Liver dry matter in 1.7-10 g fish (Table 3, Figure 4), ranging between 28 and $41 \%$, showed a linear relationship with diet composition $(p<0.0001)$, higher with high dietary lipid and low-medium dietary protein, and slightly decreasing with higher dietary carbohydrate. Liver lipid, measured as total fatty acids (TFA) and ranging between 10 and $25 \%$ of wet weight, also showed a linear relationship with diet composition $(p<0.0001)$ with largely similar properties as the variation in dry matter. Liver protein had relatively low variation, ranging between 10 and $12 \%$ of wet weight, and showed the opposite relationship to lipid and dry matter $(p=0.011)$, reaching a maximum at low lipid, medium protein, and high carbohydrate. Liver ash also followed a linear relationship $(p=0.0036)$ and increased with decreasing lipid and increasing protein, with minor positive effect of increasing carbohydrate (Tables S1 and S2).

In 15-50 g fish, liver dry matter ranged between 35 and $46 \%$ of wet weight (Table 3, Figure 4 ) and varied according to a linear model $(p=0.002)$ with the higher levels at increasing lipid and decreasing protein and carbohydrate. Liver lipid (TFA), ranging between 19 and 35\%, varied with diet composition according to a linear model $(p \leq 0.0001)$, in a similar manner as dry matter. This is similar to results in Experiment 1, but at a higher liver lipid level. Liver protein, ranging between 10 and 13\%, showed the opposite, linear $(p<0.0001)$ relationship with diet composition, decreasing with increasing lipid and increasing with higher protein. There was only a minor effect of dietary carbohydrate. These results were also similar to those observed in Experiment 1, but more marked. No diet relationship was observed for liver ash in this trial (Table S1).

A similar pattern as that observed for the liver dry matter and lipid was observed for muscle dry matter and lipid 


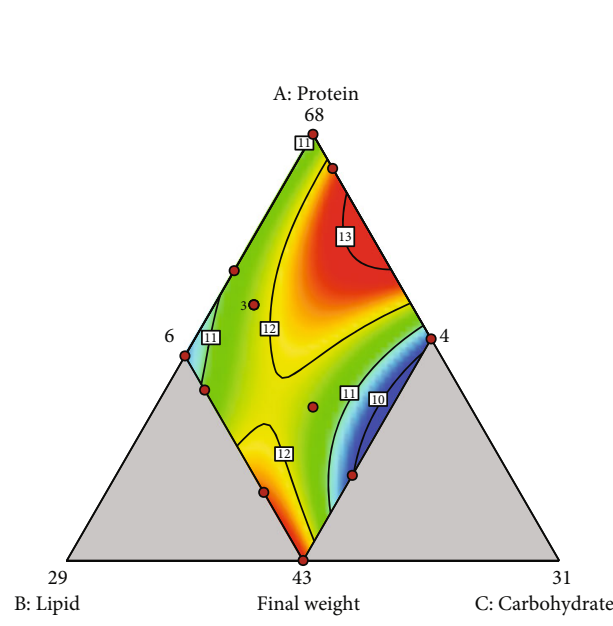

(a)

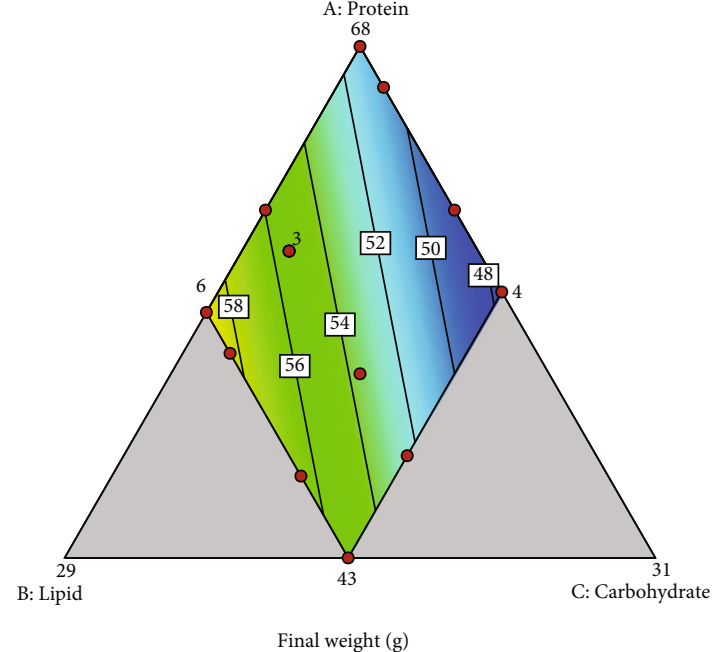

(b)

FIgURe 3: Variation in final weight (g) (white boxes in the figures indicate modelled weight along the lines) of lumpfish fed diets varying in protein lipid and carbohydrate according to a three-dimensional mixture design in Experiment 1 (a): fish size 1.7-10 g, special cubic model $(p=0.035)$; Experiment 2 (b): fish size $15-50 \mathrm{~g}$, linear model $(p=0.002)$.

(Table 3, Figure 5). They followed linear models in both fish sizes $(p<0.0001)$, increasing with increasing lipid and decreasing protein, however with less dependency on dietary carbohydrate. In $1.7-10 \mathrm{~g}$ fish, the dry matter values ranged between 8 and $11 \%$ of wet weight and lipid values between 0.6 and $3.8 \%$ of wet weight. Muscle protein (linear model, $p=0.019$ ), ranging between 6 and $8 \%$, showed the opposite relationship with diet composition compared to liver protein. It increased with increasing lipid and decreasing dietary protein and carbohydrate, showing the highest levels at medium protein, high lipid, and low carbohydrate, similar to growth. Ash content of the muscle, ranging between 0.9 and $1.1 \%$ of wet weight (linear model, $p=0.0037)$, increased with increasing lipid and decreased with increasing carbohydrate and protein, in contrast to the observation for ash in the liver.

In 10-50 g fish, muscle dry matter (Table 3, Figure 5) was directly proportional with increasing dietary lipid/decreasing dietary protein, with no effect of dietary carbohydrate. Muscle lipid (TFA), ranging from 1.1 to $6.1 \%$, increasing strongly with increasing lipid, and slightly with increasing carbohydrate. The effects on muscle lipid were like in Experiment 1, but stronger. On the other hand, muscle protein, ranging from 6.7 to $8.2 \%$, did not show significant relationship to diet composition, neither did muscle ash.

Plasma TAG was also directly correlated with dietary lipid (linear model, $p<10^{-4}$ ), with negligible effect of dietary carbohydrate (Table S1 and S2). The other plasma components: glycogen, cortisol, lactate, magnesium, and cholesterol, were not affected by the dietary treatments (Table S1).

Figure S2 contains data from $15-50 \mathrm{~g}$ fish fed the diets with $4 \%$ and $17 \%$ lipid. It shows that the water content in the liver and muscle of lumpfish was lower $(p=0.01$ and $p=0.0006)$ and the lipid content was higher $(p=0.0008$ and $p=0.00001)$ in the fish fed the diets with high dietary lipid. The protein content was lower in livers of fish fed the high lipid diets $(p=0.0001)$, but unchanged in muscle $(p>0.05)$. Ash contributed to approximately $1 \%$ of the wet weight, while the rest, perhaps corresponding to the amount of carbohydrate, accounted for less than 1.

\subsection{Effect of Dietary Macronutrient Balance on Fish Welfare} Score and Cataract. In 1.7-15g fish, the welfare score sum index (described in Table 2) ranged from 4.25 to 6.4 with no effects of the diets (Table 3 ). Fin injuries (dorsal, caudal, pectoral, and pelvic fins checked) were the most common findings with scores ranging from 0.55 to 2.55 per fin type, while the jaw, skin, and operculum had scores in the range of 0-0.2. In 15-50 g fish, there was a trend of increasing welfare score (e.g., more injury) with decreasing levels of dietary lipid, with no effect of carbohydrate or $\mathrm{P}(p=0.12$, Table S2). Fin erosion was the only injury detected.

At the start of the trial with 15-50 g fish, 8 of 25 fish had cataract score 1 , and one fish had score 2 . At termination, all examined fish showed symptoms of cataract. The scores varied between 3.6 and 5.7 on a tank basis, with no significant effects of the dietary treatments (Table S1).

3.5. Effect of Dietary Macronutrient Balance on Gene Expression in Primary Head Kidney Leukocytes. Expression of $I L-1 \beta$ and $I L-6$ (Figure 6) in head kidney cells from Lumpfish fed diet HC and HL was significantly stimulated compared to respective controls $(p<0.0001)$ when isolated head kidney cells were exposed to LPS in vitro. Fish fed the HP diet showed an overall lower expression of $I L-1 \beta$ and $I L-6(p=0.0028)$. IL-1 $\beta$ responded adequately to LPS challenge $(p<0.05)$, while the response in $I L-6$ was insignificant. The overall transcription of TNF $\alpha$ (Figure 6) was higher in the $\mathrm{HC}$ diet than in the HL diet, with intermediate response in the HP diet $(p<0.05)$. TNF $\alpha$ in leukocytes from fish fed the HC diet responded significantly to both LPS and PIC challenge compared to their respective controls $(p<0.05)$, while those from fish fed the HL diet responded to LPS 

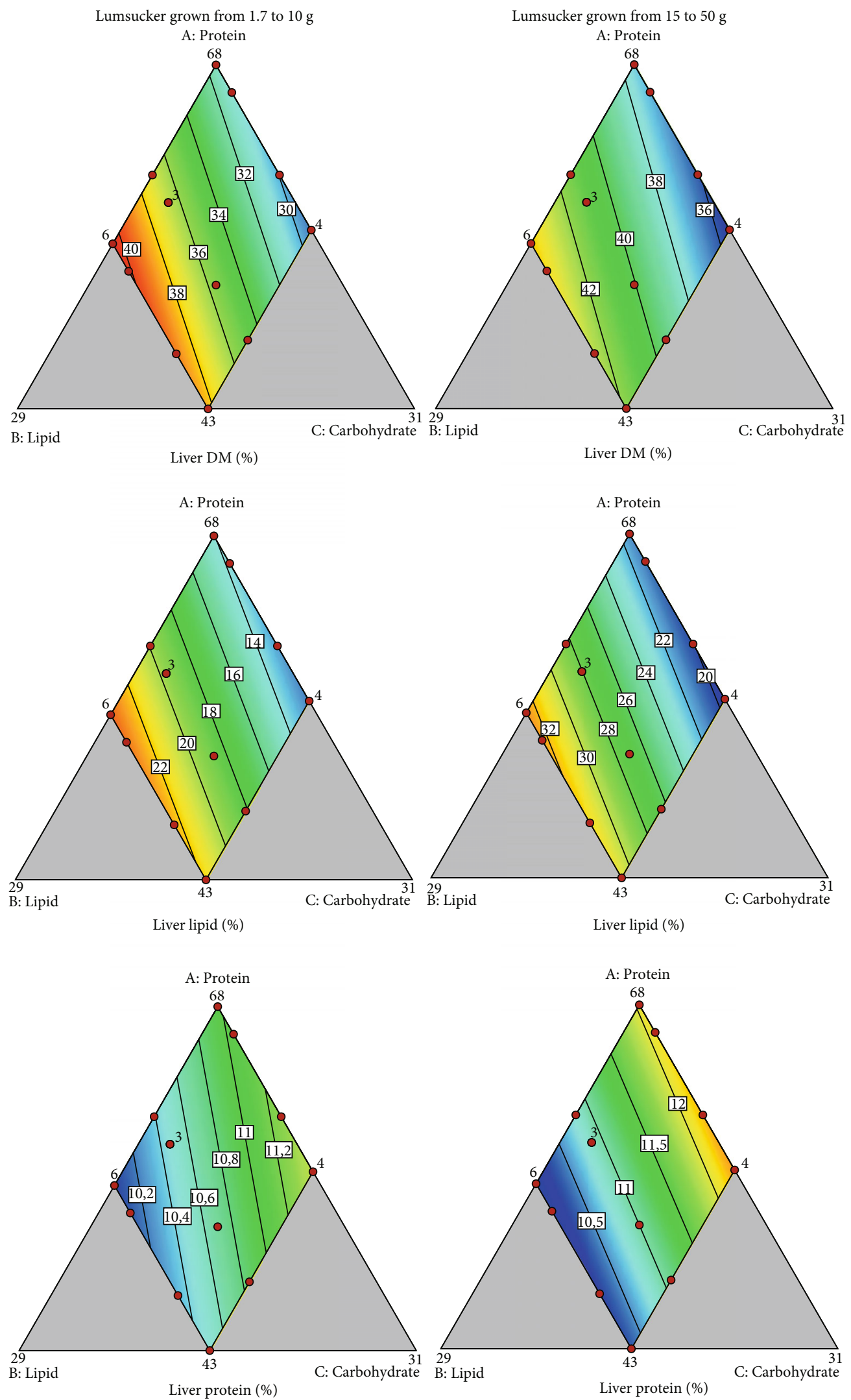

FIGURE 4: Variation in composition of macronutrients in liver of lumpfish fed diets varying in protein lipid and carbohydrate according to a three-dimensional mixture design in fish (1.7-15 g and 15-50 g, respectively) (white boxes in the figures indicate modelled weight along the lines). Linear models, protein in Experiment $1, p=0.01$; other figures, $p<10^{-4}$. 


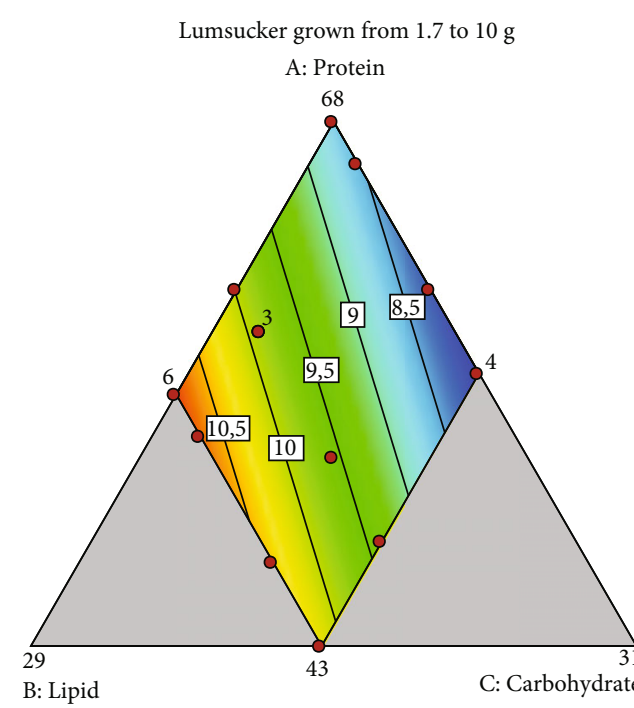

Muscle DM (\%)

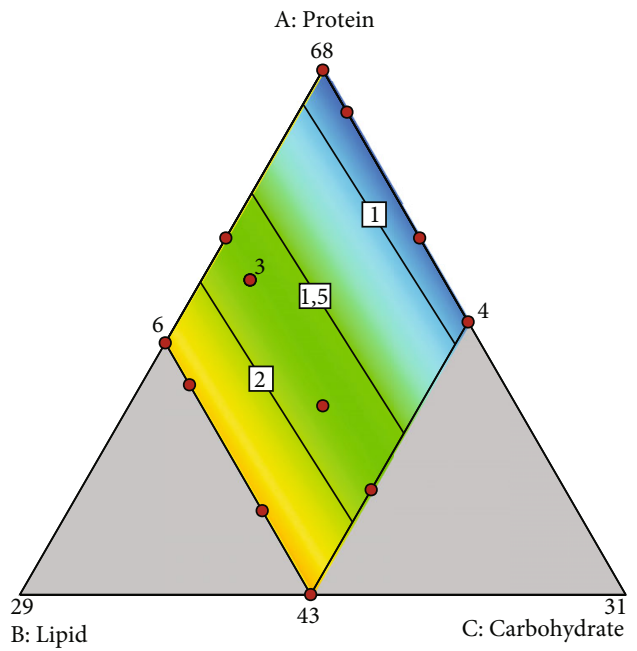

Muscle lipid (\%)
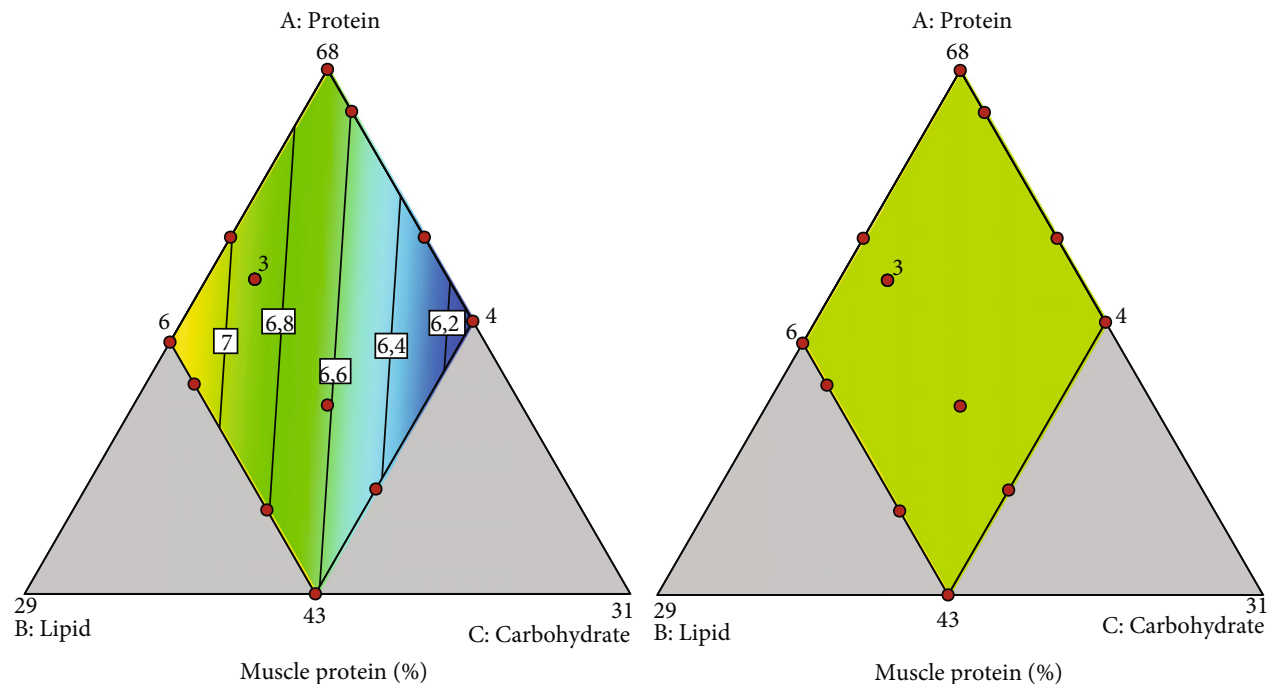

FIGURE 5: Variation in composition of macronutrients in muscle of lumpfish fed diets varying in protein lipid and carbohydrate according to a three-dimensional mixture design in fish (1.7-15 g and 15-50 g, respectively) (white boxes in the figures indicate modelled weight along the lines). Linear models, protein in Experiment 1, $p=0.02$; in Experiment 2, not significant; other figures, $p<10^{-4}$. 
challenge, only $(p<0.05)$. There was no LPS or PIC stimulation of TNF $\alpha$ in leucocytes from fish fed the HP diet. Head kidney leukocytes isolated from lumpfish given the HL diet showed generally a higher transcription of $C D 83$ (Figure 6, $p<0.0001)$ than those from the two other diets. LPS or PIC challenge did not influence CD83 transcription significantly in fish from any of the diet groups. Head kidney leukocytes isolated from lumpfish given the HL and HP diets expressed the transcription factor $N F \kappa \beta$ differently than the HC diet $(p<0.0001$, Figure 6). LPS or PIC challenge did not influence $N F \kappa \beta$ transcription in any of the diets.

When compared to respective controls, expression of TollLike Receptor 3 (TLR3) (Figure 6) was not stimulated in leukocytes that were exposed to virus mimic (PIC), in fish from any of the diet groups. Expression was similar in leukocytes from fish fed the different diets. AhR1 transcription in leukocytes isolated from lumpfish given the HL diet $(p=0.0068)$ was higher than in the two other diets (Figure 6), with no effect of LPS or PIC stimulation. The antiapoptotic marker $B c l X$ (Figure 6) showed a generally higher transcription response in leukocytes isolated from lumpfish given the HL diet than in leukocytes from fish fed the HC diet $(p=0.04)$, the HP diet being intermediate. There was no effect of LPS or PIC stimulation on $B c l X$ expression, when compared to respective controls. MHCII transcription showed no differences between diets or treatment (results not shown).

\section{Discussion}

In the present study, growth in 1.7-10 g lumpfish responded according to a special cubic model, with growth maxima at both high and low lipid levels. Growth and all other measured responses in 10-50 g fish showed a linear relationship with diets, mainly driven by the dietary lipid level. The diets high in lipid had a positive effect on growth, especially at medium protein/low carbohydrate levels. The results also showed a trend of better welfare in 10-50 $\mathrm{g}$ fish fed the diets high in lipid. On the other hand, the high lipid gave an accumulation of lipid in muscle liver and plasma of the fish. The data of immune response in head kidney cells exposed to bacterial and virus mimics showed that the diet with maximum protein and that with the lowest protein combined with high lipid/low carbohydrate were suboptimal.

At the start of the study, the developmental stage at which lumpfish can be fed conventional formulated diets had to be determined. Although gastric glands appear at 10 days posthatch in lumpfish [25], it may take some more time to develop a functional stomach with secretion of acid and pepsinogen, as seen in some other marine fish larval species $[26,27]$. In practical lumpfish culture, farmers often give the larvae formulated feed from first-feeding, based on the early morphological appearance of a stomach [25]. The feed applied is usually one especially developed for fish larvae, with high levels of easily digestible ingredients such as water-soluble protein and phospholipids [34]. In the present study, we measured gastric $\mathrm{pH}$ in fish with a full stomach and found that it did not become acidic before the fish reached 1-2 g body weight. Although Martinsen [25] performed a thorough histological study, a closer look on the functionality of the digestive tract of lumpfish larvae and adjustment of larval diets and feeding regimes needs further work.

In Experiment 1 (1.7-10g), the optimal diet for growth seemed to be shifting from one high in protein, optimal for most fish larvae [34], to one high in lipid (17\%), as indicated to be optimal for the fish of $15-50 \mathrm{~g}$ in the present study. The optimal diet for growth in 10-50 g fish had a high level of lipid (17\%), a low level of carbohydrate (6\%), and a medium level of protein $(55 \%)$. This diet was at the edge of our design, so we do not know if the result would have been different if the design had contained even higher lipid levels.

Body dry matter and nutrient composition varied with dietary input. The results were largely similar for $1.7-10 \mathrm{~g}$ fish and $15-50 \mathrm{~g}$ fish. The exception was muscle protein, which varied slightly but significantly in the small fish, but was constant in the larger fish. The variation in all nutrients was mainly driven by dietary lipid with a small or no effect of the $\mathrm{C} / \mathrm{P}$ ratio. When the $\mathrm{C} / \mathrm{P}$ ratio did have an effect, the maximum dry matter and lipid and the minimum liver protein were found in fish fed the diet with $17 \%$ lipid, $6 \%$ carbohydrate, and $50 \%$ protein, similar as for growth.

The utilization of carbohydrates in lumpfish seems to be quite inefficient, firstly indicated by the negative effect of carbohydrate on growth. Secondly, carbohydrate would correspond to the "rest" in Figure S2, and retention in the tissues appears to be very low at less than $1 \%$ of wet weight.

Lumpfish have an extraordinarily high-water content, especially in the muscle, in the present study analyzed to be $85-90 \%$. Moreover, a large subcutaneous space contains gelatinous connective tissue containing approximately $95 \%$ water. In comparison, the content of water in muscle from juvenile cod is in the range of $80 \%$ and that in Atlantic salmon, near 65\%. Davenport and Kjørsvik [35] noted that lumpfish have close to neutral buoyancy in sea water, obtained mainly by the high water content and partly by lipid deposition in the muscle. Since it lacks a swim bladder and is a slow swimmer, it uses its low density/high water content to stay buoyant.

In a previous study [36], we found that spawned eggs from farmed lumpfish had a higher dry matter and lipid content than those from wild fish. Many other nutrients, including some free amino acids vitamins and minerals, were also present in higher concentrations in eggs from the farmed fish, perhaps indicating too low water content and osmotic imbalance. The diet used in the study contained $16 \%$ lipid and $59 \%$ protein on dry matter. This hypothesis was strengthened in an epidemiological study of cataract [37], where some of the free amino acids were also very high in muscle and lenses of farmed compared to wild lumpfish. It was hard to find a clear correlation with cataract severity in this study, but again, it was concluded that farmed lumpfish had developed an osmotic or metabolic imbalance. The present study shows that at high dietary lipid levels, lipids take the place of water in the tissues, a well-known feature in animals. In the liver, lipid also replaced other components such as protein (Figure S2). The present study therefore confirmed that the dietary variation and thereby the water content of the fish as indicated by tissue water content did not affect cataract frequency. However, osmolarity was not 
IL-1 $\beta$
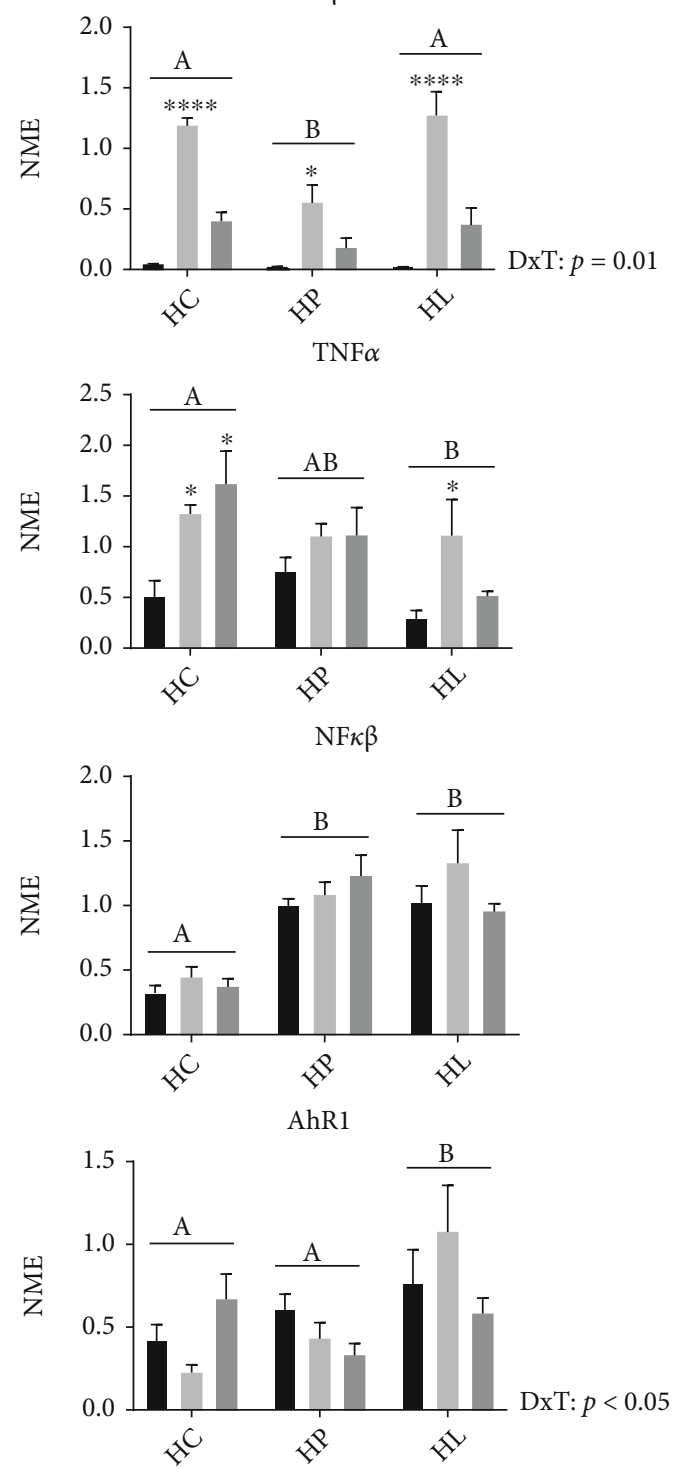

IL-6
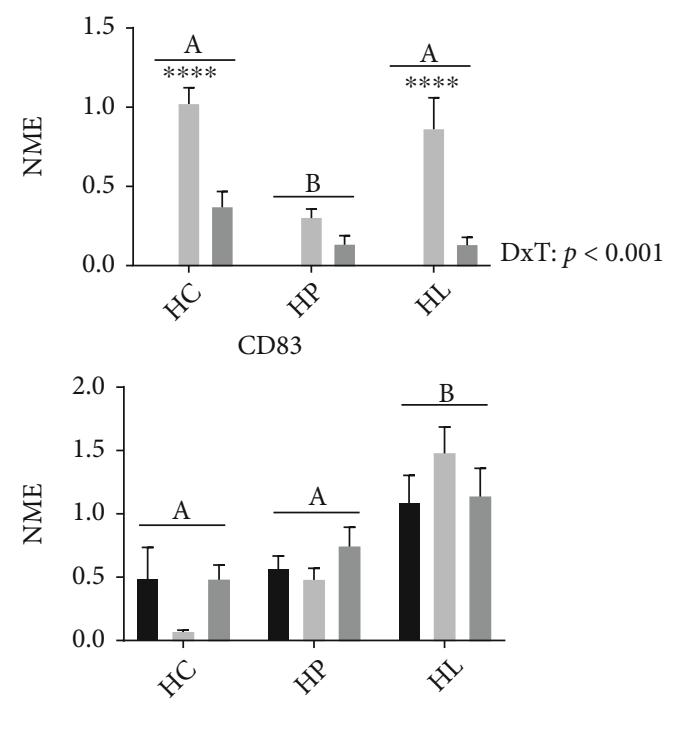

TLR3
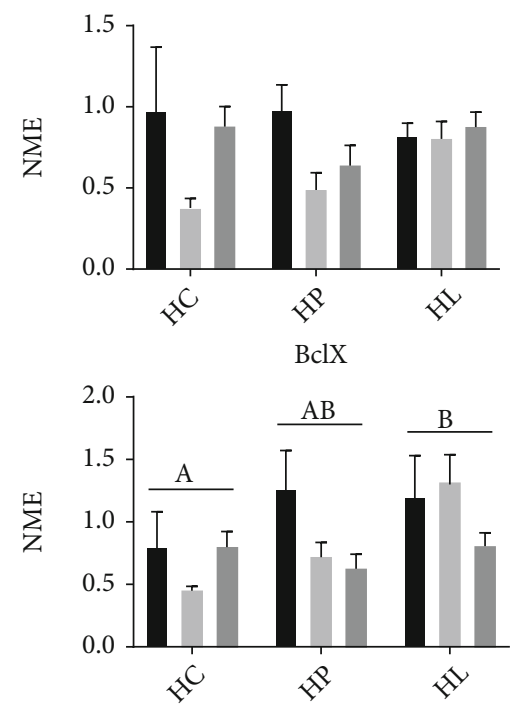

- Control
- LPS
- PIC

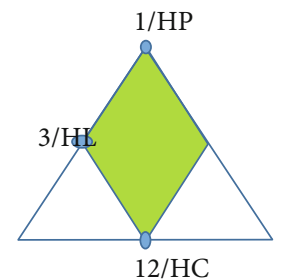

FIGURE 6: Effects of adding the bacterial mimic lipopolysaccharide (LPS) and the virus mimic polyinosinic acid : polycytidylic acid (PIC) on expression of immune genes in primary cultures of leucocytes isolated from lumpfish head kidney fed selected diets. Diets are indicated in the attached triangle (simplified Figure 1, diet 1/HP, high protein, diet 3/HL, high lipid medium protein and low carbohydrate diet 12/HC, high carbohydrate, high lipid and low protein, mean \pm SEM; control, $n=4$; LPS, $n=5$; PIC, $n=3$. Two-way ANOVA. Letters designate overall significant differences between diets, while asterisks designate significant differences between treatments when compared to the respective controls within a specific diet; ${ }^{* * * *} p<0.0001$ and $^{*} p<0.05$. Interaction between diet and treatment (DxT) is given where appropriate). 
measured and osmotic imbalance in the fish tissues cannot be excluded.

In the wild, lumpfish mainly eat gelatinous plankton and crustaceans, such as amphipods and decapods. In the stomach content of 547 lumpfish caught in the North Atlantic Ocean, $83 \%$ of the dry weight was from gelatinous plankton, $11 \%$ from crustaceans, and 6\% unidentified [38]. Lucas [39] found that the dry weight of the jellyfish, Aurelia aurita, varied between 3.07 and $3.91 \%$ of wet weight, and of the dry weight, approximately $70 \%$ was ash. Similar results were found for the mesopelagic jellyfish Periphylla periphylla [40]. Furthermore, the carbohydrate content in both $A$. aurita and $P$. periphylla was very low. In $P$. periphylla, the dry matter content was $4.8 \%$ [41]. The protein content in dry matter was $19.7 \%$ and lipid $9.3 \%$. Based on this, one can speculate that the lumpfish needs a diet with high water content, a large fraction of material that is not readily bioavailable, a protein to lipid ratio of approximately $2: 1$ and low carbohydrate. This protein to lipid ratio is not far from that of the optimal diet in the present study. Lumpfish are able to eat an amount of A. aurita corresponding to their body weight in 24 hours [38]. Crustaceans are generally nutrient rich and will contribute with protein, vitamins, and minerals [34], which can compensate for the apparent nutrient poor main diet of gelatinous plankton.

Due to the susceptibility of lumpfish to diseases, we analyzed immune responses of head kidney cells from fish fed three of the most extreme diets; the diet with maximum protein (HP), that high in lipid, low in carbohydrate and with medium content of protein (HL) and that with minimum protein, high lipid and high carbohydrate (HC). Lumpfish fed the $\mathrm{HC}$ and $\mathrm{HL}$ diets responded adequately when their leukocytes where challenged with LPS, inducing transcription of the proinflammatory genes IL- $1 \beta$, IL- 6 , and TNF $\alpha$ above respective controls. These observations resemble LPS-induced responses in other marine species $[7,42]$ and indicate that the $\mathrm{HC}$ an HL diets induce a functional innate immune response in lumpfish.

However, control cultures of isolated leukocytes from fish fed either HC, HP, or HL transcribed more of CD83, $n f \kappa \beta$, TLR3, AHR1, or Bclx than leukocytes that were exposed to LPS or PIC. If these observations are signaling that these diets are suboptimal and thus induce a general and constant transcription of these genes in the fish immune cells, it needs to be further explored.

Especially dietary effects during viral challenge need to be further evaluated as no TLR3 transcription response was detected. More viral markers should be evaluated. TLR3 is affected by PIC in other marine species [42]. In conclusion, the LPS-induced immune response was normal in the HL diet with the highest growth, but not in the diets with maximum and minimum levels of protein.

\section{Summary and Conclusions}

The aim of our study was to clarify how the dietary balance between protein, lipid, and carbohydrate affects growth, welfare, cataracts, and health with focus on immune responses in farmed lumpfish juveniles and, as far as possible, find the optimum balance between dietary macronutrients. For growth, the optimal diet for fish of 10-50 g was the one with
$55 \%$ protein, $17 \%$ fat, and $6 \%$ carbohydrate. This was at the edge of our design, so we do not know if higher lipid levels would have given even higher growth. The diets high in lipid also led to accumulation of lipid in the muscle, liver, and plasma, concomitant with lower water content, and were accompanied by a trend of better welfare score. Cataract was not affected by the dietary variation. The diets with the very low lipid contents were suboptimal with respect to growth and welfare, while the diets with maximum and minimum levels of protein gave suboptimal immune responses. From a practical point of view, farmers do not want the fish to grow too fast because larger lumpfish seem to be less efficient as louse eaters. We therefore propose that diets for lumpfish from $10-50 \mathrm{~g}$ should contain approximately 55\% protein, minimum $10 \%$ lipid, and maximum $10 \%$ carbohydrate. Such diets can also be used for lumpfish of 1.7-10 g and would be a practical and safe solution if one wants to use the same diet for lumpfish of both stages. Research on possible inclusion of inert ingredients in lumpfish feeds is important, since $70 \%$ of jellyfish, which comprises a large part of the lumpfish natural diet, is ash, probably with low bioavailability. The fraction of jellyfish which is not ash or water resembles the dietary composition giving the highest growth rates in the present study.

\section{Data Availability}

The raw data are available from the corresponding author on request.

\section{Conflicts of Interest}

The authors declare that they have no conflicts of interest.

\section{Acknowledgments}

This study was funded by the Norwegian Seafood Research Fund (FHF) as part of the project CleanFeed (\#901331). The authors acknowledge the contributions of the laboratory collaborators from IMR (Institute of Marine Research in Norway) and Nofima AS BioLab and Aqualab, for the execution of chemical analyses in feeds, fish, and raw materials; the staff of the Feed Technology Center of Nofima in Bergen for the production of the experimental feeds; and the staff of MOWI and Nofima Aquaculture Research Center Sunndalsøra for the execution of the fish feeding trials.

\section{Supplementary Materials}

Supplementary file for this manuscript: optimization of the balance between protein, lipid, and carbohydrate in diets for lumpfish (Cyclopterus lumpus) is attached. (Supplementary Materials)

\section{References}

[1] S. M. Aaen, K. O. Helgesen, M. J. Bakke, K. Kaur, and T. E. Horsberg, "Drug resistance in sea lice: a threat to salmonid aquaculture," Trends in Parasitology, vol. 31, no. 2, pp. 72-81, 2015. 
[2] L. Burridge, J. S. Weis, F. Cabello, J. Pizarro, and K. Bostick, "Chemical use in salmon aquaculture: a review of current practices and possible environmental effects," Aquaculture, vol. 306, no. 1-4, pp. 7-23, 2010.

[3] K. Overton, T. Dempster, F. Oppedal, T. S. Kristiansen, K. Gismervik, and L. H. Stien, "Salmon lice treatments and salmon mortality in Norwegian aquaculture: a review," Reviews in Aquaculture, vol. 11, no. 4, pp. 1398-1417, 2019.

[4] M. L. Groner, R. Cox, G. Gettinby, and C. W. Revie, "Use of agent-based modelling to predict benefits of cleaner fish in controlling sea lice, Lepeophtheirus salmonis, infestations on farmed Atlantic salmon, Salmo salar L," Journal of Fish Diseases, vol. 36, no. 3, pp. 195-208, 2013.

[5] A. K. D. Imsland, P. Reynolds, T. M. Jonassen et al., "Comparison of diet composition, feeding, growth and health of lumpfish (Cyclopterus lumpusL.) fed either feed blocks or pelleted commercial feed," Aquaculture Research, vol. 50, no. 7, pp. 1952-1963, 2019.

[6] A. Powell, J. W. Treasurer, C. L. Pooley et al., "Use of lumpfish for sea-lice control in salmon farming: challenges and opportunities," Reviews in Aquaculture, vol. 10, no. 3, pp. 683-702, 2018.

[7] G. P. Martins, M. Espe, Z. H. Zhang, I. G. Guimaraes, and E. Holen, "Surplus arginine reduced lipopolysaccharide induced transcription of proinflammatory genes in Atlantic salmon head kidney cells," Fish \& Shellfish Immunology, vol. 86, pp. 1130-1138, 2019.

[8] A. Nilsen, H. Viljugrein, M. V. Røsæg, and D. Colquhoun, Rensefiskhelse-kartlegging av dødelighet og dødelighetsårsaker, vol. 12, Veterinærinstituttets rapportserie, Institute of Veterinary Science, Norway, 2014, (In Norwegian).

[9] A. B. Skiftesvik, G. Blom, A. L. Agnalt et al., "Wrasse (Labridae) as cleaner fish in salmonid aquaculture - the Hardangerfjord as a case study," Marine Biology Research, vol. 10, no. 3, pp. 289$300,2014$.

[10] J. Treasurer and T. Feledi, "The physical condition and welfare of five species of wild-caught wrasse stocked under aquaculture conditions and when stocked in Atlantic Salmon, Salmo salar, production cages," Journal of the World Aquaculture Society, vol. 45, no. 2, pp. 213-219, 2014.

[11] Norwegian_Directorate_of_Fisheries, “Cleanerfish (Lumpfish and Wrasse)," 2021, https://www.fiskeridir.no/English/ Aquaculture/Statistics/Cleanerfish-Lumpfish-and-Wrasse.

[12] E. Wilmann, O. Fjetland, H. Bysheim et al., Velferd hos rensefisk, Nasjonal tilsynskampanje 2018/2019 Norwegian Food Authorothy, Oslo, Norway, 2020, In Norwegian.

[13] E. Leclercq, P. Graham, and H. Migaud, "Development of a water-stable agar-based diet for the supplementary feeding of cleaner fish ballan wrasse (Labrus bergylta) deployed within commercial Atlantic salmon (Salmon salar) net-pens," Animal Feed Science and Technology, vol. 208, pp. 98-106, 2015.

[14] A. K. Imsland, P. Reynolds, G. Eliassen et al., "Feeding preferences of lumpfish (Cyclopterus lumpus L.) maintained in open net-pens with Atlantic salmon (Salmo salar L.)," Aquaculture, vol. 436, pp. 47-51, 2015.

[15] M. D. J. Sayer, S. Gibson, G. Thomas et al., "The background and economic potential of lumpsucker culture: diversification using existing infrastructure. Final report to the MAFF/NERC LINK Aquaculture programme and to the PESCA FIFG," Tech. Rep. 225, Dunstaffnage Marine Laboratory, 2000.

[16] F. P. Willora, N. Nadanasabesan, H. R. Knutsen, C. Liu, M. Sørensen, and O. Hagen, "Growth performance, fast mus- cle development and chemical composition of juvenile lumpfish (Cyclopterus lumpus) fed diets incorporating soy and pea protein concentrates," Aquaculture Reports, vol. 17, 2020.

[17] O. Einen and A. J. Roem, "Dietary protein/energy ratios for Atlantic salmon in relation to fish size: growth, feed utilization and slaughter quality," Aquaculture Nutrition, vol. 3, pp. 127140, 1997.

[18] K. Hamre, A. Nordgreen, E. Grøtan, and O. Breck, “A holistic approach to development of diets for Ballan wrasse (Labrus berggylta) - a new species in aquaculture," Peer J, vol. 1, 2013.

[19] T. Erkinharju, R. A. Dalmo, O. Vagsnes, I. Hordvik, and T. Seternes, "Vaccination of Atlantic lumpfish (Cyclopterus lumpus L.) at a low temperature leads to a low antibody response against Aeromonas salmonicida," Journal of Fish Diseases, vol. 41, no. 4, pp. 613-623, 2018.

[20] T. Erkinharju, R. A. Dalmo, M. Hansen, and T. Seternes, "Cleaner fish in aquaculture: review on diseases and vaccination," Reviews in Aquaculture, vol. 13, pp. 189-237, 2020.

[21] S. A. Straumsnes, Antigenpresentasjon og T-celleaktivering hos rognkjeks (Cyclopterus lumpus). Thesis for the degree of Master in Biology (In Norwegian), Institute of Biological Sciences, University of Bergen, Norway, 2018.

[22] R. K. Chandra, "Nutrition and the immune system: an introduction," American Journal of Clinical Nutrition, vol. 66, no. 2, pp. 460S-463S, 1997.

[23] E. Holen, P. Araujo, N. H. Sissener, G. Rosenlund, and R. Waagb $\varnothing$, "Corrigendum to "A comparative study: difference in omega-6/omega-3 balance and saturated fat in diets for Atlantic salmon (Salmo salar) affect immune-, fat metabolism-, oxidative and apoptotic-gene expression, and eicosanoid secretion in head kidney leukocytes" [Fish Shellfish Immunol. 72 (2018) 57-68]," Fish \& Shellfish Immunology, vol. 83, pp. 449-449, 2018.

[24] E. Holen, S. Winterthun, Z. Y. Du, and A. V. Krøvel, "Inhibition of p38 MAPK during cellular activation modulate gene expression of head kidney leukocytes isolated from Atlantic salmon (Salmo salar) fed soy bean oil or fish oil based diets," Fish \& Shellfish Immunology, vol. 30, no. 1, pp. 397-405, 2011.

[25] J. L. Martinsen, Ontogeny of the Digestive System in Lumpfish (Cyclopterus Lumpus L.) Larvae in Relation to Growth and Start Feeding Diet. A Histological and Stereological Approach, [M.S. thesis], Norwegian University of Science and Technology, Ås, Norway, 2018.

[26] I. Rønnestad, M. Yufera, B. Überschär, L. Ribeiro, Ø. Sæle, and C. Boglione, "Feeding behaviour and digestive physiology in larval fish: current knowledge and gaps and bottlenecks in research," Reviews in Aquaculture, vol. 5, no. s1, pp. S59-S98, 2013.

[27] M. J. Darias, H. M. Murray, G. Martinez-Rodriguez, S. Cardenas, and M. Yufera, "Gene expression of pepsinogen during the larval development of red porgy (Pagrus pagrus)," Aquaculture, vol. 248, no. 1-4, pp. 245-252, 2005.

[28] K. Kousoulaki, E. Grøtan, T. M. Kortner et al., “Technical feed quality influences health, digestion patterns, body mineralization and bone development in farming of the stomachless cleaner fish ballan wrasse (Labrus bergylta)," Animal Feed Science and Technology, vol. 274, p. 114830, 2021.

[29] J. A. Cornell, Experiments with Mixtures, John Wiley \& Sons, Inc., 1990.

[30] $\varnothing$. Lie, R. Waagbø, and K. Sandnes, "Growth and chemical composition of adult Atlantic salmon (Salmo salar) fed dry and silage based diets," Aquaculture, vol. 69, pp. 343-353, 1988. 
[31] R. A. Sweeney and P. R. Rexroad, "Comparison of LECO FP-228 "Nitrogen Determinator" with AOAC copper catalyst Kjeldahl method for crude protein," Journal of the Association of Official Analytical Chemists, vol. 70, no. 6, pp. 1028-1030, 1987.

[32] T. Wall and E. Bjerkås, "A simplified method of scoring cataracts in fish," Bulletin of the European Association of Fish Pathologists, vol. 19, no. 4, pp. 162-165, 1999.

[33] C. Noble, S. Gismervik, M. Iversen et al., Welfare indicators for farmed Atlantic Salmon: tools for assessing fish welfare Nofima, Nofima, Ås, Norway, 2018.

[34] K. Hamre, M. Yufera, I. Rønnestad, C. Boglione, L. E. C. Conceicao, and M. Izquierdo, "Fish larval nutrition and feed formulation: knowledge gaps and bottlenecks for advances in larval rearing," Reviews in Aquaculture, vol. 5, pp. S26S58, 2013.

[35] J. Davenport and E. Kjørsvik, "Buoyancy in the Lumpsucker Cyclopterus Lumpus," Journal of the Marine Biological Association of the United Kingdom, vol. 66, no. 1, pp. 159-174, 1986.

[36] T. Jonassen, A. Nytrø, T. A. Hangstad et al., Stamfiskhold og eggproduksjon av rognkjeks, Akvaplan-niva AS, Oslo, Norway, 2016, In Norwegian.

[37] T. Jonassen, M. Hamadi, S. C. Rem $\varnothing$, and R. Waagbø, “An epidemiological study of cataracts in wild and farmed lumpfish (Cyclopterus lumpus L.) and the relation to nutrition," Journal of Fish Diseases, vol. 40, no. 12, pp. 1903-1914, 2017.

[38] M. Haugland, Rognkjeksens (Cyclopterus lumpus L) noeringsøkologi $i$ oppvekstområdene i Norskehavet - med spesiell vekt på geleplankton, Avhandling for graden Candidatus scientarum, Universitetet i Bergen, 2001, In Norwegian.

[39] C. H. Lucas, "Biochemical-composition of Aurelia Aurita in relation to age and sexual maturity," Journal of Experimental Marine Biology and Ecology, vol. 183, no. 2, pp. 179-192, 1994.

[40] C. H. Lucas, "Biochemical composition of the mesopelagic coronate jellyfish Periphylla periphylla from the Gulf of Mexico," Journal of the Marine Biological Association of the United Kingdom, vol. 89, no. 1, pp. 77-81, 2009.

[41] A. R. Alvheim, M. Kjellevold, E. Strand, M. Sanden, and M. Wiech, "Mesopelagic species and their potential contribution to food and feed security-a case study from Norway," Food, vol. 9, no. 3, 2020.

[42] E. Holen, K. K. Lie, P. Araujo, and P. A. Olsvik, "Pathogen recognition and mechanisms in Atlantic cod (Gadus morhua) head kidney cells bacteria (LPS) and virus (poly I:C) signals through different pathways and affect distinct genes," Fish \& Shellfish Immunology, vol. 33, no. 2, pp. 267-276, 2012. 